\title{
A Role for the Endocannabinoid System in the Increased Motivation for Cocaine in Extended-Access Conditions
}

\author{
Laura Orio, Scott Edwards, Olivier George, Loren H. Parsons, and George F. Koob \\ Committee on the Neurobiology of Addictive Disorders, The Scripps Research Institute, La Jolla, California 92037
}

\begin{abstract}
Extended access to cocaine produces an increase in cocaine self-administration in rats that mimics aspects of compulsive drug intake in human addicts. Although emerging evidence implicates the endogenous cannabinoid system in aspects of opioid and ethanol addiction, a role of the endocannabinoid system in cocaine addiction remains widely inconclusive. Here, we investigate the effects of systemic and intra-accumbal administration of the CB1 antagonist SR141716A (Rimonabant) on cocaine self-administration (0.5 mg/kg/infusion) under a progressive ratio (PR) schedule in rats with extended [long access (LgA); $6 \mathrm{~h} / \mathrm{d}$ ] or limited [short access (ShA); $1 \mathrm{~h} / \mathrm{d}]$ access to cocaine. LgA rats, but not ShA rats, showed an increase in cocaine intake as previously reported, and responding for cocaine by LgA rats was higher than in ShA rats under a PR schedule. Systemic SR141716A induced a dramatic dose-dependent decrease in the breakpoint for cocaine by LgA rats, whereas only the highest dose of the antagonist had a significant effect in the ShA group. Anandamide levels in the nucleus accumbens (NAc) shell were decreased in ShA rats but unchanged in LgA rats during cocaine self-administration. Both phosphorylated and total CB1 receptor protein expression were upregulated in LgA rats in the NAc and the amygdala compared with ShA and drug-naive rats, $24 \mathrm{~h}$ after last cocaine session. Finally, intra-NAc infusions of SR141716A reduced cocaine breakpoints selectively in LgA animals. These results suggest that neuroadaptations in the endogenous cannabinoid system may be part of the neuroplasticity associated with the development of cocaine addiction.
\end{abstract}

\section{Introduction}

Cocaine addiction constitutes a major health problem, and an estimated 1.6 million Americans meet the criteria for cocaine abuse or dependence (National Surveys on Drug Use and Health, 2006). Animal models for components of psychostimulant addiction have been well characterized (Ahmed and Koob, 1998; Kitamura et al., 2006) and mimic valid aspects of the loss of control over drug intake observed in humans (American Psychiatric Association, 2000; Koob, 2008). Specifically, cocaine selfadministration with extended access [long access (LgA)] gradually increases over days, whereas the intake remains stable in rats with limited access [short access (ShA)] (Ahmed and Koob, 1998; Wee et al., 2007, 2008; Specio et al., 2008). This escalated drug intake is associated with increased breakpoints or responding for cocaine under a progressive ratio (PR) schedule, suggesting an enhanced motivation to seek cocaine and/or an enhanced efficacy of cocaine reward (Paterson and Markou, 2003; Wee et al., 2008) and is also characterized by a withdrawal syndrome as measured

Received Feb. 2, 2009; revised March 9, 2009; accepted March 11, 2009.

This work was supported by National Institute on Drug Abuse (NIDA) Grant DA004398 (G.F.K.), National Institutes of Health Grant AA014619 (L.H.P.), and the Pearson Center for Alcoholism and Addiction Research. L.O. thanks Spanish Ministerio de Ciencia y Tecnología, Fundación Española para la Ciencia y la Tecnología, and Fulbright Program for a Fulbright Award (FU-2006-0200). We thank Dr. Sunmee Wee for helpful comments on the behavioral study and Mike Arends for editorial assistance. We also appreciate the excellent technical assistance of Ilham Polis, David G. Stouffer, Dr. Lily Alvarez-Jaimes, and Lindsey Porterfield. We are grateful to NIDA for providing SR141716A. This is publication number 19783 from The Scripps Research Institute.

Correspondence should be addressed to Dr. Laura Orio, Committee on the Neurobiology of Addictive Disorders, SP30-2410, The Scripps Research Institute, 10550 North Torrey Pines Road, La Jolla, CA 92037. E-mail: lorio@scripps.edu.

D0I:10.1523/JNEUROSCI.0563-09.2009

Copyright $\odot 2009$ Society for Neuroscience $\quad$ 0270-6474/09/294846-12\$15.00/0 by increased brain reward thresholds (Ahmed et al., 2002). Thus, investigations into the neuroadaptations that occur in LgA rats are invaluable for understanding the enhanced motivation to seek cocaine associated with the development of addiction.

The endogenous cannabinoid system is associated with aspects of drug addiction, as endocannabinoids (eCB) modulate the rewarding effects of ethanol, nicotine, opioids, and marijuana (for review, see Tanda and Goldberg, 2003; Lupica et al., 2004, Cohen et al., 2005; Gardner, 2005). Moreover, CB1 cannabinoid receptors are expressed in regions of the brain reward circuitry (Herkenham et al., 1990, 1991; Mailleux and Vanderhaeghen, 1992). However, the specific role of eCB in cocaine addiction remains widely inconclusive (Wiskerke et al., 2008). Whereas several studies suggest no role for CB1 receptors in cocaine selfadministration per se (Fattore et al., 1999; Martin et al., 2000; Cossu et al., 2001; Lesscher et al., 2005; Caillé and Parsons, 2006; Filip et al., 2006; Caillé et al., 2007), other reports demonstrate a CB1 receptor involvement in both the acquisition and consolidation of cocaine reward (Soria et al., 2005; Xi et al., 2008) and in relapse to cocaine-seeking behavior (De Vries et al., 2001; Xi et al., 2006). However, the above studies evaluated the effects of CB1 receptor deletion/antagonism in animals given limited access to cocaine. It is unknown if long-term extended-access cocaine exposure could alter eCB-CB1 function.

We tested the hypothesis here that alterations in eCB transmission contribute to the increased motivation for cocaine associated with stimulant use. Thus, we examined the effects of systemic and intra-accumbal injections of the CB1 receptor antagonist SR141716A (Rimonabant) on cocaine selfadministration under a PR schedule of reinforcement and 
showed a selective enhanced sensitivity in LgA rats compared with ShA rats. Additionally, LgA rats maintained an increased nucleus accumbens (NAc) eCB tone during cocaine selfadministration compared with ShA rats and showed an upregulation of both phosphorylated (pCB1) and total $\mathrm{CB} 1$ receptor protein expression in the NAc and amygdala $24 \mathrm{~h}$ after last cocaine session. Results together suggest a dramatic increased activity of the eCB system in rats with extended access to cocaine self-administration.

\section{Materials and Methods}

Animals. Sixty-eight adult male Wistar rats (Charles River) weighting 225-250 g at the start of the experiment were used. Rats were housed two or three per cage with food and water available ad libitum and maintained in a reverse $12 \mathrm{~h}$ light/dark cycle, with lights on at 8:00 A.M. Twenty-three rats did not complete the experiments because of catheter failure or health complications. In three animals, the intravenous catheter was replaced for a new one which was implanted in the left jugular vein, and two animals were excluded of analysis because of misplaced cannula locations. All procedures were approved by The Scripps Research Institute Animal Care and Use Committee and were in accordance with National Institutes of Health (NIH) guidelines (NIH Publication no. 85-23, revised 1996).

Drugs and reagents. Cocaine hydrochloride and SR141716A (Rimonabant) [N-piperidino-5-(4-chorophenyl)-1-(2,4-dichlorophenyl)-4methylpyrazole-3-carboxamide] were generously provided by the $\mathrm{Na}$ tional Institute on Drug Abuse. Cocaine $\mathrm{HCl}$ was dissolved in sterile $0.9 \%$ saline and filtered. SR141716A (Rimonabant) was dissolved in a vehicle of ethanol:emulphor:saline (1:1:18) by sonication for $30 \mathrm{~s}$ and was prepared fresh for every test session. Arachidonoylethanolamide (anandamide, AEA), 2-arachidonoylglycerol (2-AG), 1(3)-arachidonoylglycerol (1-AG), and (S)-(+)-arachidonyl-2'-hydroxy-1'-propylamide (S-2 methanandamide) were used as chromatographic standards for microdialysis and were purchased from Cayman Chemical. Rabbit anti-CB1 receptor (C1108) was purchased from Sigma. Rabbit polyclonal antipCB1 receptor (s.c.-17555) and mouse anti- $\beta$-tubulin (s.c.-53140) antibodies were purchased from Santa Cruz Biotechnology, goat anti-rabbit and goat anti-mouse IgG secondary antibodies were from Bio-Rad.

Intravenous surgery. Rats were anesthetized with $2-3 \%$ of isoflurane mixed in oxygen and implanted with a sterilized SILASTIC catheter $(0.64$ inner diameter $\times 1.19$ outer diameter $\mathrm{mm}$; Dow Corning) into the right jugular vein under aseptic conditions. The distal end of the catheter was threaded under the skin to the back of the rat and exited the skin via a metal guide cannula (22G; Plastic One). Immediately after surgery, Flunixin $(2.5 \mathrm{mg} / \mathrm{kg}$, s.c. $)$ was given as analgesic. The rats were subjected to antibiotic therapy (Timentin; $20 \mathrm{mg}$, i.v.) for at least $10 \mathrm{~d}$. Catheters were flushed daily with heparinized saline (30 USP units/ $\mathrm{ml})$. The patency of catheters was tested using methohexital sodium (Brevital; $10 \mathrm{mg} / \mathrm{ml}, 2 \mathrm{mg} / \mathrm{rat}$ ).

Cocaine self-administration procedure. After at least $5 \mathrm{~d}$ of postoperative recovery, rats were trained to self-administer cocaine during daily $1 \mathrm{~h}$ sessions under a fixed ratio 1 (FR1) schedule of reinforcement in standard operant boxes (MedAssociates). The dose of cocaine $(0.5 \mathrm{mg} / \mathrm{kg} /$ infusion) was prepared individually for each rat based on the body weight and updated every 2 or $3 \mathrm{~d}$. Cocaine at $0.5 \mathrm{mg} / \mathrm{kg} /$ infusion accounts for a highly stable self-administration behavior in rats, and previous findings showed as well that the dose of $0.5 \mathrm{mg} / \mathrm{kg} /$ infusion of cocaine is within the range of the descending limb of the cocaine dose-response selfadministration curve in rats (Xi et al., 2005; Wee et al., 2007, 2008), and thus this dose of cocaine is appropriate to measure reliable and stable dose-dependent effects. In addition, when LgA and ShA rats were compared using a dose/response test, there was an upward shift at all doses bracketing this dose (Ahmed and Koob, 1998, 1999, 2005; Deroche et al.,1999; Wee et al., 2007). The dose of cocaine was carefully chosen based on our and other's previous studies to reflect a dose where both increases and decreases in PR responding could be observed (Xi et al., 2005, 2008; Wee et al., 2007, 2008).

At the beginning of each session, rats were presented with two levers into the chamber. Responding on the right lever resulted in the $4 \mathrm{~s}$ delivery of $0.1 \mathrm{ml}$ of cocaine and the illumination of a light above the lever that lasted throughout a time-out period of $20 \mathrm{~s}$. Responding on the left lever was recorded but had no programmed consequences. Rats were trained to self-administer a higher cocaine dose ( $1 \mathrm{mg} / \mathrm{kg} /$ infusion $)$ for $2 \mathrm{~d}$ before the dose of cocaine was reduced to $0.5 \mathrm{mg} / \mathrm{kg} /$ infusion over 14 subsequent baseline sessions. After this baseline period, the rats were divided into two groups, balanced by the average number of cocaine infusions per session during the last three baseline sessions. One group of rats were allowed to self-administer cocaine $(0.5 \mathrm{mg} / \mathrm{kg} /$ infusion $)$ during daily $6 \mathrm{~h}$ sessions ( $\operatorname{LgA}$ ), whereas the other group of rats was maintained on daily $1 \mathrm{~h}$ sessions (ShA) for the next 22 sessions. Cocaine self-administration sessions were conducted $6 \mathrm{~d}$ per week.

SR141716A (Rimonabant) pretreatment on cocaine self-administration. After 22 escalation sessions, the effect of the CB1 receptor antagonist SR141716A was tested in LgA and ShA rats under a PR schedule of reinforcement. In the PR schedule, the response requirement began at one lever press/infusion and increased exponentially according to the following equation: lever press/infusion $=\left[5 \times e^{\text {(infusion number } \times 0.2)}\right]-$ 5 (Richardson and Roberts, 1996). The session length was limited to $12 \mathrm{~h}$ or ended when a rat failed to achieve the response requirement within $1 \mathrm{~h}$. Test sessions (PR) were conducted $2 \mathrm{~d}$ per week and were preceded by two FR1 cocaine self-administration session days ( $\mathrm{LgA}, 6 \mathrm{~h}$ session; ShA, $1 \mathrm{~h}$ session) to assure stable cocaine intake levels between the previous and the subsequent test session. Each rat received systemic vehicle pretreatments before four PR test sessions to habituate them to the injection procedure. Three doses of the CB1 antagonist SR141716A (0.3 mg $/ \mathrm{kg}, 1.0$ $\mathrm{mg} / \mathrm{kg}$ and $3.0 \mathrm{mg} / \mathrm{kg}$ ) and vehicle (see Drugs and reagents) were tested in a within-subject, Latin square design. The CB1 receptor antagonist was injected intraperitoneally $30 \mathrm{~min}$ before a test session. The SR141716A doses were chosen based on previous literature (Rodríguez de Fonseca et al., 1999; Navarro et al., 2001). Finally, each rat was again tested with vehicle injections in one last test session at the end of the study. No changes in responding to vehicle treatment were found on PR cocaine self-administration during and after the Latin square design.

Brain microdissection procedure. Animals from the behavioral study were allowed to self-administer cocaine (LgA, 6 h session, $n=6$; ShA, $1 \mathrm{~h}$ session, $n=6$; FR1) during a SR141716A wash-out period of at least $7 \mathrm{~d}$ after the last dose tested. For the purpose of comparison, age- and weight-matched drug-naive rats $(n=4)$ were included as a control group for the biochemical analyses. Twenty-four hours after the last escalation session rats were decapitated in random order under light isoflurane anesthesia. The brains were rapidly removed, snap frozen in 2-methylbutane, and stored at $-80^{\circ} \mathrm{C}$ until dissection. On the day of dissection, brains were mounted and sliced in a cryostat (Cryocut 1800; Reichert-Jung, Leica). Brain tissue from the prefrontal cortex (PFC; +3.20 to $+2.20 \mathrm{~mm}$ from bregma), NAc core $(+2.20$ to +0.70$)$, NAc shell $(+1.70$ to +0.70$)$, dorsal striatum $(\mathrm{DS} ;+1.70$ to +2.20$)$, bed nucleus of the stria terminalis (BNST; -0.30 to -0.80 ), amygdaloid nucleus (Amy; -1.80 to -2.80 ), ventral hippocampus (VHp; -2.80 to -4.30 ), and dorsal hippocampus ( $\mathrm{DHp} ;-4.30$ to -5.8 ) were punched out bilaterally in successive $500 \mu \mathrm{m}$ sections with the assistance of a rat brain atlas (Paxinos and Watson, 1998). Punch needles were kept on dry ice during the procedure to prevent tissue from thawing within the needle, and brain punches were subsequently kept at $-80^{\circ} \mathrm{C}$ until assay.

Western blot analysis of phosphorylated or total CB1 receptor and $\beta$-tubulin. Brain punches were sonicated in a homogenization buffer containing $50 \mathrm{~mm}$ Tris- $\mathrm{HCl}, \mathrm{pH}=7.4,10 \% \mathrm{w} / \mathrm{v}$ sucrose, $5 \mathrm{~mm}$ EDTA, 1 $\mathrm{mm}$ dithiotreitol, 1\% w/v SDS, with Protease Inhibitor Mixture and Phosphatase Inhibitor Cocktails I and II diluted 1:100 each (Sigma). Protein content was determined in homogenized samples using a detergent-compatible protein assay (Bio-Rad). Equal amounts of protein $(15 \mu \mathrm{g})$ were loaded per lane including 3-5 animals per group in each gel. In a separate experiment, equal amounts of protein $(15 \mu \mathrm{g})$ from various brain structures were loaded to compare basal brain-wide CB1 receptor and pCB1 immunoreactivies in naive animals. Proteins were separated by $10 \%$ SDS-PAGE using Tris-Glycine-SDS buffer system (Bio-Rad) and transferred to polyvinylidene membranes (GE Healthcare). Membranes were then blocked for $2 \mathrm{~h}$ in PBS containing 5\% nonfat milk to reduce 
nonspecific binding of antibodies, followed by an overnight incubation at $4^{\circ} \mathrm{C}$ with polyclonal rabbit anti-CB1 (1:500 dilution) or anti-pCB1 (Ser 317) (1:250 dilution) and mouse anti- $\beta$-tubulin (1:2500 dilution). Membranes were washed and then incubated for $1 \mathrm{~h}$ with species-specific peroxidase-conjugated secondary antibody (1:10000 dilution; Bio-Rad). Immunoreactivity was detected with an enhanced chemiluminescence (ECL) Western blot detection system (GE Healthcare), following by exposure to Amersham Hyperfilm ECL for 1-5 min. Different film exposure times were used to ensure that bands were not saturated, and immunoreactivity was quantified by ImageJ software (NIH). The antipCB1 antibody used in this study was raised against the CB1 receptor, which is phosphorylated by PKC at Ser 316 (humans)/Ser 317 (rodents) (Matsuda et al., 1990; Gérard et al., 1991; Garcia et al., 1998). The antibody recognized two bands corresponding to the glycosylated (63 $\mathrm{kDa}$ ) and the nonglycosylated $(53 \mathrm{kDa})$ protein, both reflecting functional pCB1 receptor protein (Howlett et al., 1998; Porcella et al., 2000). Both glycosylated and nonglycosylated phosphorylated forms were quantified and expressed as total $\mathrm{pCB} 1$ protein. The antibody for total $\mathrm{CB} 1$ receptor density recognized one band of $64 \mathrm{kDa}$ corresponding to the monomeric form of the fully glycosylated receptor (Fusco et al., 2004) that was quantified and expressed as total CB1 receptor protein [the antibody recognized also one nonspecific band of $33 \mathrm{kDa}$, which is due probably to the secondary antibody used; for details, see Fusco et al. (2004)]. $\beta$-Tubulin was used as a loading control and so the immunoreactivity of CB1 and $\mathrm{pCB} 1$ receptors was corrected for $\beta$-tubulin levels.

Intracerebral microdialysis cannula implantations. To investigate cocaine's regulation of eCB levels in $\operatorname{LgA}$ and ShA rats during cocaine self-administration, another group of rats was trained as described above. After the escalation period (22 sessions), rats were anesthetized ( $2-3 \%$ isoflurane) and implanted with a guide cannula (SciPro) aimed at the NAc shell using a stereotaxic frame with the tooth bar at $-3.3 \mathrm{~mm}$ below the interaural zero. Coordinates for the shell cannula implantation were as follows: $+1.6 \mathrm{~mm}$ from bregma, \pm 0.8 mediolateral, and -5.7 mm below dura (Paxinos and Watson, 1998). Cannulae were implanted in the right or left NAc shell of the rats in random order. To avoid disruption in animal behavior resulting from surgery, rats were allowed to self-administer cocaine during at least six more sessions before the microdialysis experiment.

Probe implantation and in vivo microdialysis. For probe implantation, each animal was lightly anesthetized (1-2\% isoflurane), and the dialysis probes ( $2 \mathrm{~mm}$ polyethyl sulfone membrane, $15 \mathrm{kDa}$ MW cutoff; SciPro) were inserted in the guide cannulae and secured with a light layer of cement (Double/Bubble Epoxy; Hardman). The probes were perfused overnight with artificial CSF $(0.1 \mu \mathrm{l} / \mathrm{min})$ composed of the following: 149 $\mathrm{NaCl} \mathrm{nM,} 2.8 \mathrm{KCl}, 1.2 \mathrm{CaCl}_{2}, 1.2 \mathrm{MgCl}_{2}, 0.25$ ascorbic acid, and 5.4 D-glucose. The morning of the microdialysis experiment, the artificial CSF was replaced by an artificial CSF solution containing 30\% (w/v) hydroxypropyl- $\beta$-cyclodextrin, and probes were perfused for $90 \mathrm{~min}$ at $0.6 \mu \mathrm{l} / \mathrm{min}$ flow. Subsequently, dialysis samples were collected at $15 \mathrm{~min}$ intervals during the baseline period $(90 \mathrm{~min}$ ) and subsequent operant cocaine self-administration ( $90 \mathrm{~min})$. Animals remained in the same cage and room during the microdialysis perfusion and were transferred to the operant chambers in the same room exclusively for cocaine self-administration.

Liquid chromatography/mass spectrometry analysis of dialysate eCB content. Dialysate levels of AEA, 2-AG, and 1-AG were determined using high-performance liquid chromatography coupled with electrospray ionization mass spectrometry. 2-AG levels were calculated by summing 1-AG and 2-AG peak areas to control for 2-AG degradation over time. The procedure used has been previously described in detail (Caillé et al., 2007).

Intracerebral infusion cannulas. Animals were trained as described in the cocaine self-administration procedure. After 24 escalation sessions, rats were anesthetized ( $2-3 \%$ isoflurane) and implanted with bilateral microinfusion guide cannula (22 gauge, $12 \mathrm{~mm}$ length, stainless steel) that terminated $2 \mathrm{~mm}$ above the surface of the NAc (from bregma: anterior-posterior, +1.7 , medio-lateral, \pm 0.9 , dorso-ventral, -5.4 from dura) (Paxinos and Watson, 1998). After postoperative recovery, rats were allowed to self-administer cocaine until similar self-administration rates to those before surgery were established before the SR141716A testing.

Intra-NAc SR141716A (Rimonabant) testing on PR cocaine selfadministration. The effects of local SR141716A administration on cocaine self-administration under a PR schedule were evaluated in a separate group of animals. Animals were trained for responding in a PR schedule during a total of four sessions (two sessions before intracerebral surgery and two sessions after surgery) which were always preceded by cocaine FR1 sessions. After establishment of stable self-administration behavior, animals received an initial sham microinjection (insertion but no liquid infusion) immediately before a PR cocaine session to acclimate them to the procedure and to produce the initial tissue damage from injection insertion. Subsequently, vehicle and SR141716A (1.0 and 3.0 $\mu \mathrm{g}$ per side) were injected via bilateral 33 gauge microinjections that extended $2 \mathrm{~mm}$ beyond the tip of the guide cannulas. Infusions of $0.5 \mu \mathrm{l}$ per side were made over a $2 \mathrm{~min}$ period, followed by an additional $1 \mathrm{~min}$ to allow drug diffusion before injector removal. The doses of SR141716A for intracerebral microinjections were chosen on the basis of a ratio of $\sim$ 1000:1 for systemic/intracerebral microinjection dosing (Xi et al., 2006) and after our previous work with SR141716A (Caillé et al., 2007). Intra-NAc administration of SR141716A was tested immediately before cocaine PR sessions in a counter balance order across the rats, and each dose was tested only once in each animal.

Histology. Microdialysis probe locations were examined after completion of the experiments in all the animals. Rats were killed by decapitation and brains removed and rapidly frozen on dry ice. Brains were coronally sliced in a cryostat, and the probe placements were verified with the help of a rat atlas (Paxinos and Watson, 1998).

Cannula placements for intra-NAc infusions were examined as follows: frozen coronal brain section $(60 \mu \mathrm{m})$ were dehydrated and rehydrated in ethanol, stained in $0.1 \%$ cresyl violate acetate for $10 \mathrm{~min}$, and coverslipped for histological verification of the implant location under a light microscope.

Statistical analyses. Data were analyzed using GraphPad Prism version 4.0 (GraphPad Software). Cocaine intake was expressed as the mean number of infusions in both the first hour of the session and in the total session for each group of rats. Cocaine self-administration was compared across daily sessions over the initial 22 sessions using repeated-measures two-way ANOVA followed by a Bonferroni post hoc test (access times daily session). The effect of pretreatment of SR141716A on cocaine PR self-administration was compared between $\operatorname{LgA}$ and ShA rats using repeated-measures two-way ANOVA with cocaine access as the betweensubjects factor and SR141716A dose as the within-subjects factor followed by the Bonferroni post-test. Additionally, when a significant access times dose interaction was found, one-way ANOVA followed by Newman-Keuls post hoc test was conducted on simple main effects, and Student's $t$ test was performed on the appropriate pairing (vehicle-injected rats). To identify possible rate-dependent effects, a median split analysis was performed on the LgA animal's response under a PR schedule (cocaine injections per session) that yielded high and low subgroups, which were compared using an independent samples $t$ test. Subsequently, the percentage change from baseline after SR141716A administration was compared for the high and low responding groups using an independent samples $t$ test. Differences in baseline dialysate AEA and 2-AG concentrations between LgA and ShA rats were analyzed by two-tailed Student's $t$ test. Subsequently, dialysate AEA and 2-AG levels were expressed as a percentage of the average six dialysate baseline concentrations for each group. Changes in dialysate sample content between groups were investigated measuring the area under the curve (AUC) for AEA and 2-AG of the transformed data. The AUC was calculated for each animal by subtracting each percentage of baseline data points from 100 and summing all data points collected during the experimental period. Calculated cumulative AUC was then compared between groups by Student's $t$ test for AEA and 2-AG. Additionally, repeated-measures two-way ANOVA analysis of the calculated data was used to investigate interaction between groups. Percentage of changes from baseline levels in each group were reported by using repeated-measures one-way ANOVA after NewmanKeuls multiple comparison test when a significant interaction or main effect was found. 

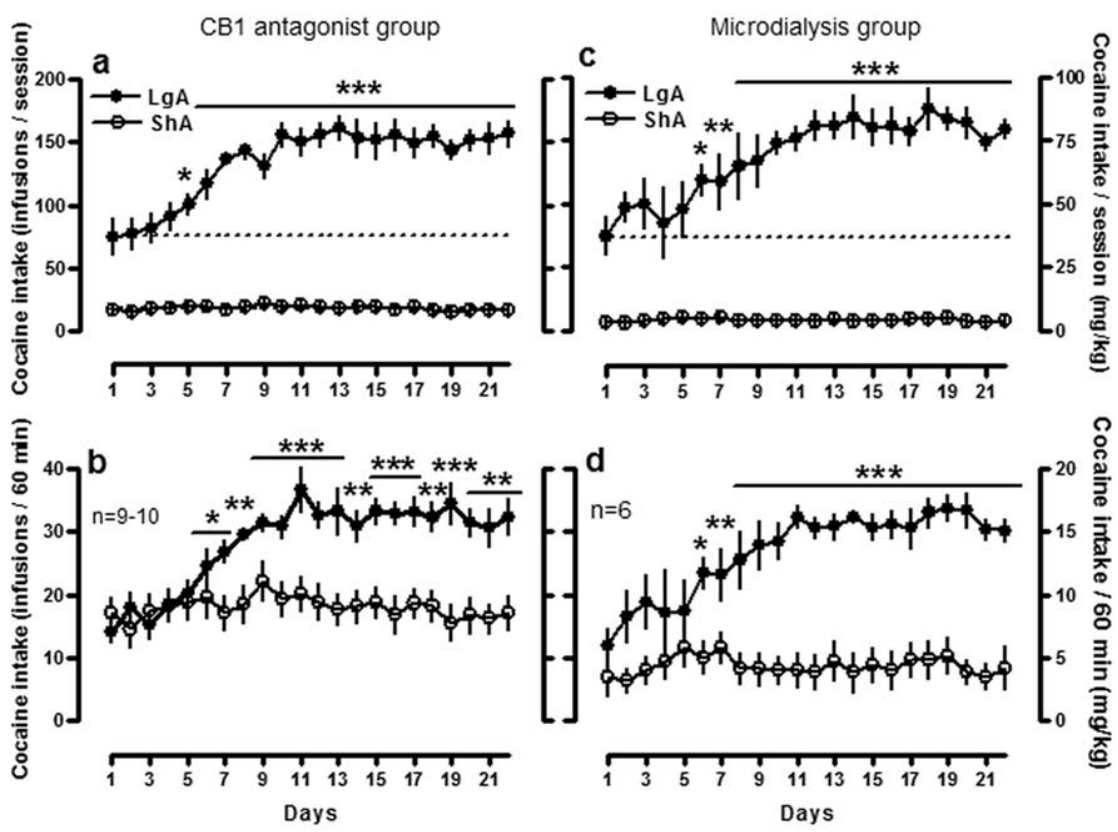

Figure 1. Cocaine self-administration under an FR1 schedule during the escalation period. Left panels $(\boldsymbol{a}, \boldsymbol{b})$ are data from animals in the CB1 receptor antagonist study, and right panels $(\boldsymbol{c}, \boldsymbol{d})$ are data from animals in the microdialysis study. Top panels $(\boldsymbol{a}, \boldsymbol{c})$ are data from the entire $6 \mathrm{~h}$ sessions, and bottom panels $(\boldsymbol{b}, \boldsymbol{d})$ are data from the first hour of the sessions. Filled circles correspond to cocaine ( $0.5 \mathrm{mg} / \mathrm{kg} /$ infusion) extended-access rats ( $6 \mathrm{~h}$ session, $\mathrm{LgA}$ ), and open circles correspond to cocaine limited-access rats ( $1 \mathrm{~h}$ session, ShA). Data are expressed as the mean \pm SEM of the number of cocaine infusions on the left axis and $\mathrm{mg} / \mathrm{kg}$ on the right axis. ${ }^{*} p<0.05,{ }^{* *} p<0.01,{ }^{* *} p<0.001$ compared with session one.

Data from Western blot analyses were expressed as a percentage of the drug-naive control group and were analyzed using one-way ANOVA followed by Newman-Keuls multiple comparison test when a significant $F$ value was obtained.

\section{Results}

Cocaine self-administration under a fixed-ratio schedule in ShA and LgA rats

CB1 receptor antagonist group

A two-way ANOVA found a significant interaction between group and daily session in escalation of cocaine selfadministration $(0.5 \mathrm{mg} / \mathrm{kg} /$ infusion $)$ within a whole session $\left(F_{(21,374)}=7.27, p<0.0001\right)$ as well as during the first hour of each session $\left(F_{(21,374)}=3.08, p<0.0001\right)$. Additionally, there were main effects of group $\left(F_{(1,374)}=2561, p<0.0001\right.$; first hour $\left.F_{(21,374)}=169.7, p<0.0001\right)$ and daily session $\left(F_{(21,374)}=7.58\right.$, $p<0.0001$; first hour $\left.F_{(21,374)}=3.85, p<0.0001\right)$ on cocaine self-administration levels. Subsequent analyses revealed that cocaine self-administration in ShA rats $(n=10)$ remained stable over 22 sessions (Fig. $1 a, b$, open circles). However, LgA rats ( $n=$ 9) self-administered more cocaine over time, with the increase becoming evident in session five (within the whole session), and in session six (during the first hour), compared with respective cocaine intake in session one (Fig. $1 a, b$, filled circles). Escalated cocaine self-administration by LgA rats was maintained over the course of the study.

\section{Endocannabinoid microdialysis group}

Similarly, in the microdialysis study, $\operatorname{LgA}$ rats $(n=6)$ showed an escalation in the cocaine intake over 22 sessions, compared with session one, within the $6 \mathrm{~h}$ session (Fig. 1c, filled circles) and during the first hour of each session (Fig. 1d), which started in session number six. A two-way ANOVA found a significant interaction between group and daily session in cocaine selfadministration within session $\left(F_{(21,220)}=3.61, p<0.0001\right)$ and during the first hour session $\left(F_{(21,220)}=\right.$ $2.446, p<0.001)$. Additionally, there were main effects of group $\left(F_{(1,220)}=1406, p<\right.$ 0.0001 ; first hour $F_{(1,220)}=400.6, p<$ $0.0001)$, and daily session $\left(F_{(21,220)}=3.61\right.$, $p<0.0001$; first hour $F_{(1,220)}=2.44, p<$ $0.0001)$ in the levels of cocaine selfadministration. Self-administration in the ShA group $(n=6)$ remained stable over the 22 sessions (Fig. $1 b, d$, open circles).

\section{Effect of CB1 receptor antagonist} SR141716A (Rimonabant) on cocaine self-administration under a PR schedule in LgA and ShA rats

To determine whether CB1 activation drives the increased motivation for $\mathrm{CO}$ caine observed in dependent animals, we tested a CB1 antagonist on cocaine selfadministration under a PR schedule of reinforcement. LgA rats responded $\sim 228$ times at the active lever (cumulative response) to achieve breakpoint of 52.79 ratio/infusion (12.67 reinforcements) (Fig. 2, left panel). ShA rats responded $\sim 97$ times to achieve an average breakpoint of $25.83 \quad(9.3$ reinforcements) (Fig. 2, right panel). The breakpoint for cocaine $(0.5 \mathrm{mg} / \mathrm{kg} /$ infusion) in vehicle-injected rats was significantly higher in LgA rats versus ShA rats (Student's $t$ test, $\left.{ }^{\#} p<0.01\right)$.

Figure 2 shows the effects of pretreatment with SR141716A $(0.3,1.0$ and $3.0 \mathrm{mg} / \mathrm{kg}$, i.p.) on the breakpoint for cocaine in both long and short access conditions. A two-way ANOVA between SR141716A pretreatment and cocaine access showed a significant interaction between both factors $\left(F_{(3,51)}=5.80, p=0.0017\right)$ and a main effect of SR141716A on cocaine breakpoint $\left(F_{(3,51)}=\right.$ 23.49, $p<0.0001)$. Additional post-test revealed a significant reduction in the breakpoint for cocaine in LgA rats at all doses of SR141716A tested versus vehicle in the same access condition (Fig. 2) $\left(0.3 \mathrm{mg} / \mathrm{kg},{ }^{*} p<0.05 ; 1.0\right.$ and $\left.3.0 \mathrm{mg} / \mathrm{kg},{ }^{* *} p<0.001\right)$. Similar analysis in ShA rats showed that pretreatment with 0.3 and $1.0 \mathrm{mg} / \mathrm{kg}$ doses of SR141716A did not modify the breakpoint for cocaine compared with vehicle-injected rats in the same access condition $[p>0.05$, nonsignificant (n.s.) $]$, and only the highest dose $(3.0 \mathrm{mg} / \mathrm{kg})$ had a significant effect in the limited access animals $\left({ }^{*} p<0.05\right)$. Furthermore, even with the lowest dose of SR141716A, there was no longer a significant difference between LgA and ShA rats in responding for cocaine $(p>0.05$, n.s.). One-way ANOVA analyses identified a main effect of SR141716A dose in LgA and ShA rats $\left(F_{(3,24)}=18.42, p<0.0001\right.$ and $F_{(3,27)}=5.24, p<0.01$, respectively) and post hoc tests confirmed a reduction in cocaine breakpoint in LgA rats at 1.0 and $3.0 \mathrm{mg} / \mathrm{kg} \mathrm{SR} 141716 \mathrm{~A}$ dose $(p<0.001)$ and in ShA rats at 3.0 $\mathrm{mg} / \mathrm{kg}$ dose $(p<0.05)$, compared with the respective vehicleinjected animals. Finally, SR141716A at $3.0 \mathrm{mg} / \mathrm{kg}$ decreased cocaine breakpoints in the LgA group to even lower ratios than ShA vehicle-treated rats ( $t$ test, $p<0.01$ ). This fact suggests that high doses of SR141716A may interact with neuroadaptative changes in the LgA group that are not present in the ShA group and/or that $\mathrm{CB} 1$ receptor signaling provides a general influence on the motivational effects in LgA animals beyond simply conferring the 


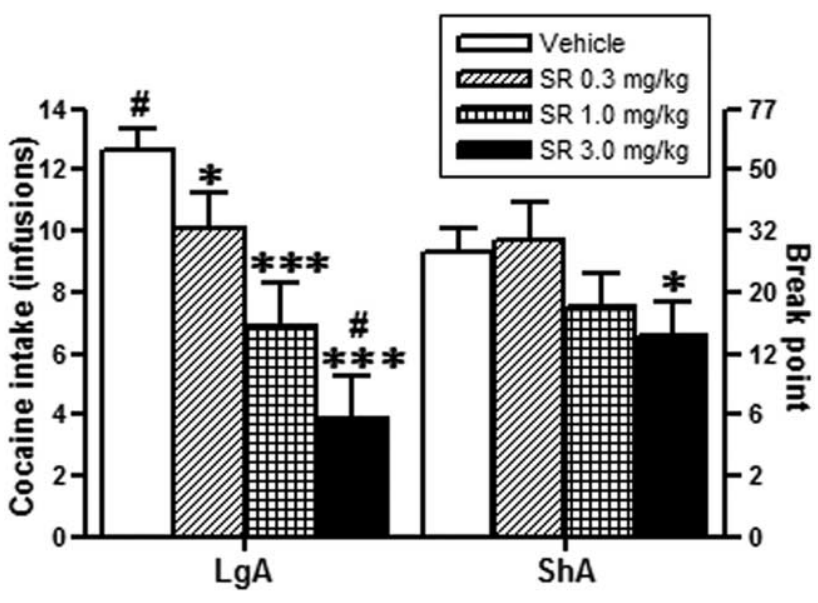

Figure 2. Effects of systemic CB1 receptor antagonist SR141716A on the breakpoint for cocaine in LgA and ShA rats. SR141716A (SR, Rimonabant) was injected (intraperitoneally) 30 min before the test session. Sessions under a PR schedule ended when rats did not achieve cocaine $(0.5 \mathrm{mg} / \mathrm{kg} /$ infusion) reinforcement within $1 \mathrm{~h}$. Data are expressed as the mean \pm SEM of the number of infusions per session on the left axis and the breakpoint (maximal ratio per infusion) on the right axis. Bars on the left side are data from cocaine extended-access ( $\mathrm{LgA})$ rats, and bars on the right side are data from limited-access (ShA) rats. Responding for cocaine was different under a PR schedule in vehicle-injected rats between the access conditions: ${ }^{\sharp} p<$ 0.01 compared with ShA. SR141716A ( 0.3 and $1.0 \mathrm{mg} / \mathrm{kg})$ decreased the breakpoint for cocaine selectively in LgA rats compared with vehicle-injected animals; the highest dose of SR141716A $(3.0 \mathrm{mg} / \mathrm{kg})$ had a significant effect in both $\mathrm{LgA}$ and ShA rats compared with their respective controls: ${ }^{*} p<0.05,{ }^{* * *} p<0.001$ compared with vehicle-injected rats in the same access condition. Different from ShA vehicle-injected rats: ${ }^{*} p<0.01$.

Table 1. Cocaine intake (milligrams per kilograms) by LgA and ShA rats during systemic SR141716A testing (PR sessions)

\begin{tabular}{lllc}
\hline & Cocaine $(\mathrm{mg} / \mathrm{kg}), \mathrm{LgA}$ & Cocaine $(\mathrm{mg} / \mathrm{kg})$, ShA & $p$ value \\
\hline SR vehicle & $6.33 \pm 0.34$ & $4.65 \pm 0.40^{*}$ & $<0.01$ \\
SR $0.3 \mathrm{mg} / \mathrm{kg}$ & $5.06 \pm 0.58$ & $4.85 \pm 0.62$ & n.s. \\
SR $1.0 \mathrm{mg} / \mathrm{kg}$ & $3.45 \pm 0.70$ & $3.75 \pm 0.55$ & n.s. \\
SR $3.0 \mathrm{mg} / \mathrm{kg}$ & $1.95 \pm 0.69$ & $3.30 \pm 0.53$ & n.s. \\
\hline
\end{tabular}

The amount of cocaine ingested by LgA and ShA rats on the test days was calculated based on data in Figure 2. Data in the table are represented as mean \pm SEM. Analysis of the cocaine intake paired data presented in the table ( $\mathrm{LgA}$ vs ShA; $t$ test) shows differences in the amount of cocaine between vehicle-injected LgA and ShA animals and no differences in the amount of cocaine ingested between the two groups on the other test days. These data support the hypothesis that SR141716A acted independently of the amount of cocaine currently in the rat's system during testing. SR, SR141716A; different from cocaine LgA in the same condition: ${ }^{*} p<0.01$; n.s., nonsignificant.

increased cocaine intake and/or breakpoints observed in LgA versus ShA animals.

To address the possibility that higher response rates would be more susceptible to pharmacological modulation by the CB1 antagonist, we conducted a median split analysis on the $\operatorname{LgA}$ animals' response rates. A median split analysis of the response of the LgA animals in a PR schedule (cocaine injections per session) yielded high and low responder subgroups with mean leverpresses $( \pm$ SEM) $14.6 \pm 0.25$ and $11.83 \pm 0.79$, respectively. SR141716A induced equivalent decreases in percentage change from baseline at all doses tested regardless of whether the animals had high or low response rates initially. For example, SR141716A at dose of $1 \mathrm{mg} / \mathrm{kg}$ produced $41.1 \pm 9.98 \%$ and $43.63 \pm 11.41 \%$ decrease in responding in the high and low responders, respectively. This further supports the hypothesis that SR141716A acted independently of response rate and was more potent in LgA animals.

The amount of cocaine in the rat's system during testing was calculated based on data in Figure 2 and is represented in Table 1. Analysis of the cocaine intake data presented in Table 1 shows that on the test days there were no robust differences in the amount of cocaine ingested between the two groups. For example, there are no differences in the amount of cocaine in the rat's system on the test days after SR141716A 0.3 and $1.0 \mathrm{mg} / \mathrm{kg}$ pretreatment $(5.06 \mathrm{mg} / \mathrm{kg}$ vs $4.85 \mathrm{mg} / \mathrm{kg}$ and $3.45 \mathrm{mg} / \mathrm{kg}$ vs 3.75 $\mathrm{mg} / \mathrm{kg}$, respectively). However, during those test days, SR141716A decreased responding selectively in the LgA group and not in the ShA group (Fig. 2). This supports the hypothesis that SR141716A acted independently of the amount of cocaine currently in the rat's system during testing. Rather, the data suggest that SR141716A altered the motivation for obtaining cocaine in the LgA group.

Endocannabinoid levels during cocaine self-administration in the NAc shell of rats with a history of LgA and ShA to cocaine To test whether eCB transmission is differentially affected by extended versus limited access to cocaine, we measured eCB levels during cocaine self-administration in LgA and ShA rats using in vivo microdialysis. AEA and 2-AG levels (see Materials and Methods) were measured in the NAc shell, where changes in eCB transmission were reported previously after heroin and ethanol self-administration (Caillé et al., 2007).

Baseline AEA and 2-AG levels are depicted in Figure $3 d$. No differences in the baseline levels of either AEA or 2-AG were found between ShA and LgA rats (Student's $t$ test, $p>0.05$, n.s.), although AEA baseline levels in the LgA group were relatively lower $(\sim 37 \%)$ compared with the ShA group $(2.89 \pm 0.33$ vs $1.80 \pm 0.51 \mathrm{nM}, p>0.05$, n.s.). As expected, LgA rats selfadministered more cocaine than ShA rats during the $90 \mathrm{~min} \mathrm{mi-}$ crodialysis session (Student's $t$ test, $p<0.01$ ). Total cocaine intake during the test session was $21.63 \pm 5.67 \mathrm{mg} / \mathrm{kg}$ for LgA rats and $5.33 \pm 1.28 \mathrm{mg} / \mathrm{kg}$ for ShA rats. Figure $3 c$ shows the cocaine response record for a representative animal in each group. AUC analysis revealed a significant difference in AEA levels between LgA and ShA rats during the entire session (Fig. $3 a$ ) [Student's $t$ test (AUC), $\left.{ }^{*} p<0.05\right]$. Two-way ANOVA revealed a significant interaction between group and cumulative AUC over time for AEA levels $\left(F_{(6,48)}=4.30, p \leq 0.01\right)$ and main effects of group $\left(F_{(1,48)}=6.30, p<0.05\right)$ and time $\left(F_{(6,48)}=17.79, p<0.0001\right)$ in the AEA dialysate. Further analyses revealed that cocaine selfadministration in ShA rats produced rapid decreases in AEA (Fig. $3 a$ ) (repeated-measures one-way ANOVA, ${ }^{*} p<0.05$ ), whereas AEA levels in the LgA group remained similar to baseline during the 90 min session (see Fig. 6a) (repeated-measures one-way ANOVA, $p>0.05$, n.s.). Regarding 2-AG levels, no statistical difference in the AUC analysis was found between groups (Fig. $3 b$ ) [Student's $t$ test (AUC), $p>0.05$, n.s.]. Two-way ANOVA analyses of 2-AG dialysate failed to find an interaction between group and the cumulative AUC over time $\left(F_{(6,48)}=1.02, p>\right.$ 0.05 , n.s. $)$, although there was a main effect of time in the $2-A G$ levels $\left(F_{(6,48)}=10.27, p<0.0001\right)$. Further analyses revealed decreases in 2-AG levels over time in the ShA group (Fig. $3 b$ ) (repeated-measures one-way ANOVA, ${ }^{*} p<0.05$ ) but no significant effect in the LgA group (Fig. 3b) (repeated-measures oneway ANOVA, $p>0.05$, n.s.).

\section{Histology}

The active portion of the dialysis membrane was located in the NAc shell between 1.6 and $1.7 \mathrm{~mm}$ anterior to bregma in all cases $(n=10)$ (Fig. 4).

Cannula placements for intra-accumbal infusions were located in the NAc between 2.28 and $2.76 \mathrm{~mm}$ anterior to bregma (see Fig. 9). Two animals (one LgA and one ShA rats) 
a

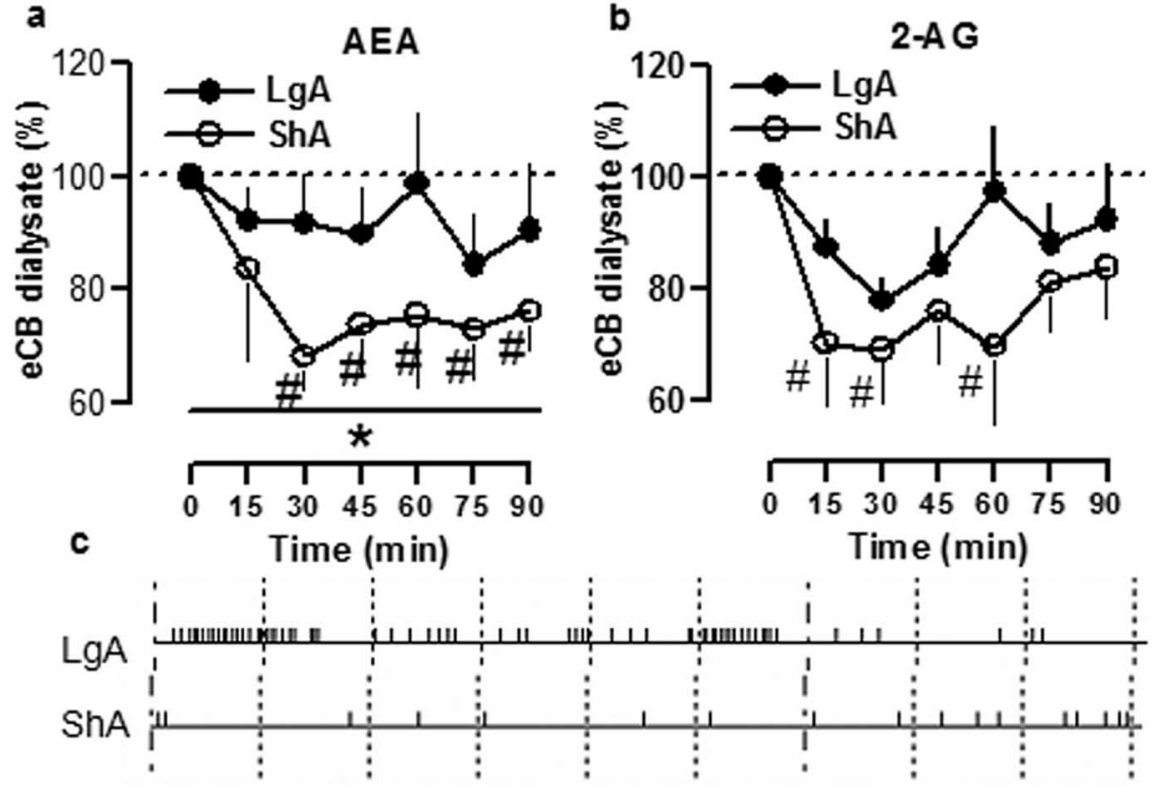

d

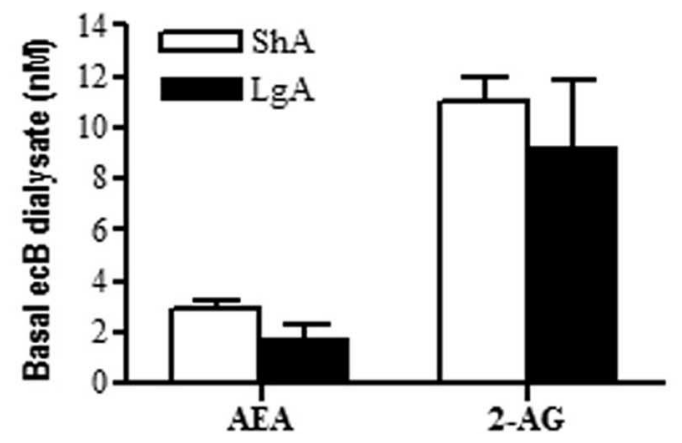

Figure 3. In vivo microdialysis for AEA and 2-AG in the NAc shell of $\mathrm{LgA}$ and ShA rats during cocaine self-administration. NAc shell eCB dialysates were collected every $15 \mathrm{~min}$ in cocaine LgA (filled circles) and ShA (open circles) rats. Time 0 represents basal levels for AEA $(\boldsymbol{a})$ and 2-AG $(\boldsymbol{b})$, which were calculated as mean of the six dialysated samples collected before the selfadministration session. Values are expressed as percentage of the baseline samples $\pm S E M$. Differences in the AUC between LgA and ShA: ${ }^{*} p<0.05$. Different from baseline levels in the same condition: ${ }^{\#} p<0.05$ (one-way ANOVA, Newman-Keuls test). Central panel (c) represents the response records for representative dialysated LgA and ShA animals during the cocaine selfadministration test session. Small marks represent an intravenous infusion of cocaine, and larger marks represent 10 min periods within the session. Basal concentrations for AEA and 2-AG are depicted in $\boldsymbol{d}$.

had misplaced cannulas, and therefore, only rats with cannulas implanted in the NAc shell were included in the analysis $(n=10)$.

\section{$\mathrm{CB} 1$ and $\mathrm{pCB} 1$ receptor distribution in the brain}

Figure 5 shows brain-wide total CB1 and phosphorylated CB1 receptor distribution in a representative drug-naive animal. We observed that functional CB1 receptors are widely distributed in the brain and concentrated in addiction-related brain areas such as the NAc core and shell, amygdala, bed nucleus of the stria terminalis, and prefrontal cortex, in agreement with other reports (Herkenham et al., 1990, 1991; Mailleux and Vanderhaeghen, 1992; Tsou et al., 1998; Hermann and Lutz, 2005). The pattern of CB1 receptor expression slightly differs from the pCB1 levels, with high density of both proteins observed in prefrontal cortex, dorsal striatum, and hippocampus, in accordance with the well known regulatory effect of $\mathrm{CB} 1$ receptors on many other processes in the brain, including locomotion and memory. The bar graph in Figure 5 represents the quantification of total CB1 receptor and pCB1 receptor density (see Materials and Methods) normalized by $\beta$-tubulin levels $(51 \mathrm{kDa})$ in each brain area and expressed as a ratio (Fig. 5).

Increased phosphorylated and total CB1 receptor protein expression in the amygdala and NAc of cocaine LgA rats High densities of phosphorylated CB1 receptor protein were observed in $\mathrm{LgA}$ rats compared with ShA and drug-naive rats specifically in the NAc core $\left(F_{(2,10)}=6.25\right.$, $p<0.05)$, NAc shell $\left(F_{(2,11)}=6.45, p<\right.$ $0.05)$ and the amygdala $\left(F_{(2,11)}=4.50, p<\right.$ $0.05) 24 \mathrm{~h}$ after the last cocaine escalation session (Fig. 6) (Newman--Keuls multiple comparison test: ${ }^{*} p<0.05$ compared with ShA; ${ }^{\star} p<0.05$ compared with drug-naive rats). In contrast, no changes in $\mathrm{pCB} 1 \mathrm{im}$ munoreactivity were found in other brain structures such as the prefrontal cortex (Fig. 6), bed nucleus of the stria terminalis, dorsal striatum, and hippocampus (data not shown). There were no differences in pCB1 immunoreactivity between ShA and drug-naive rats $(p>0.05$, n.s.) in any of the brain structures tested (Fig. 6). Moreover, cocaine self-administration did not change $\beta$-tubulin levels in any region tested (Fig. 6).

To elucidate whether $\mathrm{pCB} 1$ receptor increases reflected changes in total $\mathrm{CB} 1$ receptor densities, we analyzed total CB1 receptor immunoreactivity across the groups in the brain structures where we found an increase in pCB1 receptor (Fig. 7). Total CB1 receptor protein was increased in LgA rats in the NAc core $\left(F_{(2,12)}\right.$ $=4.851, p<0.05)$, the $\operatorname{NAc}$ shell $\left(F_{(2,12)}=\right.$ $4.225, p<0.05)$ and the amygdala $\left(F_{(2,16)}\right.$ $=5.483, p<0.05) 24 \mathrm{~h}$ after the last cocaine escalation session (Fig. 7) (Newman--Keuls multiple comparison test: ${ }^{\#} p<0.05$ compared with ShA; ${ }^{*} p<0.05$ compared with drug-naive rats). No changes in CB1 receptor were observed between ShA and drug-naive rats ( $p>0.05$, n.s.). Whereas most drugs of abuse alter $\mathrm{CB} 1$ receptor density in different directions (Basavarajappa et al., 1998; Gonzalez et al., 2002), no changes were observed after noncontingent cocaine administration in limbic forebrain (Gonzalez et al., 2002), which is in agreement with the lack of receptor changes observed in our ShA rats. However, we observed increased CB1 receptor density specifically in cocaine dependent animals, and similarly, opioidand ethanol-dependent animals showed a permanent CB1 receptor upregulation in reward-related areas and enhanced sensitivity to reward disruption induced by cannabinoid receptor antagonists (Rodríguez de Fonseca et al., 1999; Navarro et al., 2001, 2004; Rimondini et al., 2002).

Intra-NAc infusion of the $\mathrm{CB} 1$ receptor antagonist SR141716A reduces cocaine PR responding selectively in LgA rats

To confirm the hypothesized mechanism for the systemic effects of SR141716A, we performed an additional experiment where we 
infused bilaterally the $\mathrm{CB} 1$ antagonist SR141716A into the NAc immediately before a cocaine PR session. Rats were previously trained under an FR1 schedule in conditions of limited or extended access (see Materials and Methods), and cocaine self-administration data (Fig. 8b,c) were analyzed by a mixed-factor two-way ANOVA. The analysis identified a significant interaction between group and daily session within a whole session (Fig. $8 b$ ) $\left(F_{(23,230)}=3.08, p<0.0001\right)$ and during the first hour of each session (Fig. 9c) $\left(F_{(23,230)}=1.78, p=0.02\right)$. Additionally, there were main effects of group $\left(F_{(1,230)}=\right.$ 14.12, $p=0.004)$, and daily session $\left(F_{(23,230)}=3.79, p<0.0001\right.$; first hour $\left.F_{(23,230)}=4.74, p<0.0001\right)$ on cocaine self-administration levels. Subsequent analyses revealed that cocaine selfadministration in ShA rats $(n=6)$ remained stable over 24 sessions (Fig. 8b,c, open circles). However, LgA rats $(n=6)$ self-administered more cocaine over time, with the increase becoming evident in session nine, compared with respective cocaine intake in session one (Fig. $9 a, b$, filled circles).

Under a PR schedule, LgA rats achieve an average breakpoint of $\sim 48$ ratio/infusion (11.0 reinforcements) (Fig. $8 a$, left side), whereas ShA rats responded achieve an average breakpoint of $\sim 12$ ratio/infusion (5.8 reinforcements) (Fig. $8 a$, right side). The breakpoint for cocaine in vehicle-injected rats was significantly higher in LgA rats versus ShA rats (Student's $t$ test, ${ }^{\#} p<0.05$ ). Figure $8 a$ shows the effects of bilateral infusions of SR141716A $(0.0,1.0$, and $3.0 \mu \mathrm{g} / \mathrm{side} ; 0.5 \mu \mathrm{l}$ per side in $2 \mathrm{~min})$ on the breakpoint for cocaine in both long and short access conditions. A two-way ANOVA between SR141716A pretreatment and cocaine access showed a significant interaction between both factors $\left(F_{(2,16)}=4.56, p=0.027\right)$. Additional analysis revealed that bilateral SR141716A accumbal infusions reduced breakpoints for cocaine selectively in LgA rats (Fig. $8 a$, left panel) $\left(F_{(2,8)}=12.87\right.$, ${ }^{* *} p<0.01$ ), and no effect was observed in the ShA group (Fig. $8 a$, right panel) $(p>0.05$, n.s. $)$.

A potential confound is that the site-specific injections may diffuse to other surrounding brain regions. Thus, the degree of spread of the antagonist was determined by an injection of $0.5 \mu \mathrm{l}$ of cresyl violet using the same procedure as the microinjections. The dye was localized within the NAc in all animals included in the statistics. Two animals (one ShA and one LgA) were removed from the study because of misplaced cannula. Those animals presented no reduction in responding for cocaine after the administration of the antagonist ( $p>0.05)$. Within the NAc, the majority of cannulas were placed in the shell subregion (see histology in Fig. 9). In two LgA animals, one of the two cannulas had an angle or was shifted in medio-lateral plane so that it touched the core subregion, and the other cannula was located in the medial shell. Those animals did present reductions in breakpoints for cocaine.

\section{Discussion}

The following findings provide evidence that eCB system neuroplasticity contributes to the increased motivation for cocaine intake under extended-access conditions: (1) blockade of CB1 re-

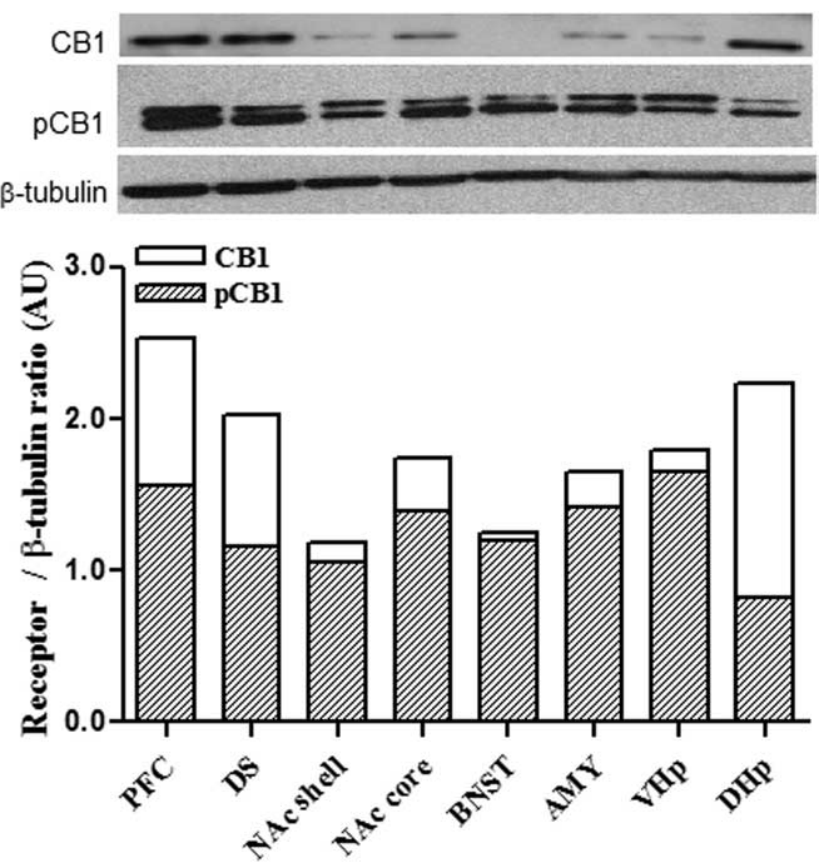

Figure 5. Regional differences in total $C B 1$ receptor and $p C B 1$ protein expression in the brain. Top, Representative immunoblots for total CB1, pCB1 receptors, and the loading control $\beta$-tubulin show the pattern of functional $C B 1$ receptor distribution throughout the brain. Bottom, The bar graph shows the quantification of the single band corresponding to $C B 1$ receptor protein expression and the double band (see Materials and Methods) corresponding to $\mathrm{pCB} 1$ receptor immunoreactivity, both normalized by $\beta$-tubulin immunoreactivity. Data are expressed as receptor/ $\beta$-tubulin immunoreactivity ratio. AU, Arbitrary units.

ceptors by SR141716A systemic administration decreases the breakpoint for cocaine dose-dependently in LgA rats, whereas only the highest dose of the antagonist has an effect in the ShA group; (2) NAc shell eCB tone is maintained by LgA rats during cocaine self-administration, whereas decreases in eCB levels are 


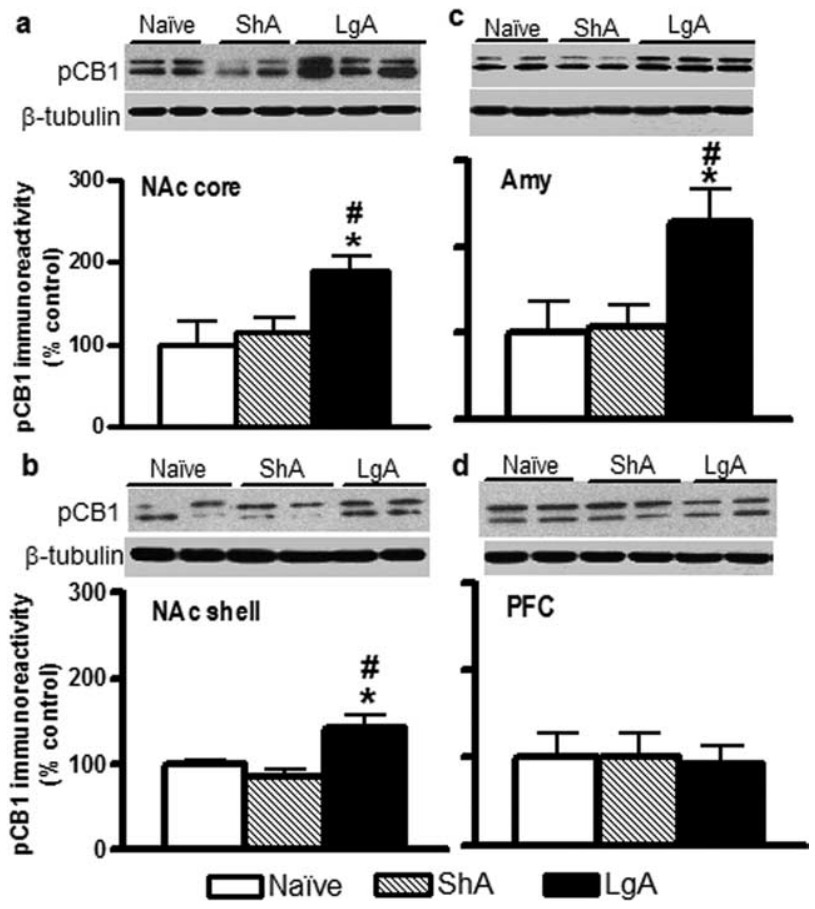

Figure 6. Western blot analysis of pCB1 receptor immunoreactivities in NAc core, NAc shell, Amy, and PFC of drug-naive and cocaine ShA and LgA rats. Top panels show representative immunoblots for $\mathrm{pCB} 1$ and the loading control $\beta$-tubulin in nucleus accumbens core $(\boldsymbol{a} ; \mathrm{NAc}$ core), nucleus accumbens shell ( $\boldsymbol{b}$; NAc shell), Amy (c), and PFC (d). Bar graphs show the quantification of pCB1 receptors immunoreactivity (double-band quantification; see Materials and Methods). Data in graphs are represented as mean $\pm \operatorname{SEM}(n=4-5)$ and expressed as percentage values of the drug-naive rats for each group in every brain structure after normalization by $\beta$-tubulin. Animals were killed $24 \mathrm{~h}$ after the last cocaine session. LgA, Long access to cocaine (filled bars); ShA, short access to cocaine (striped bars); Naïve, drug-naive rats (open bars). Different from drug-naive rats, ${ }^{*} p<0.05$; different from ShA rats, ${ }^{\#} p<0.05$. $\beta$-Tubulin expression was constant across the groups ( $p>0.05$, n.s.).

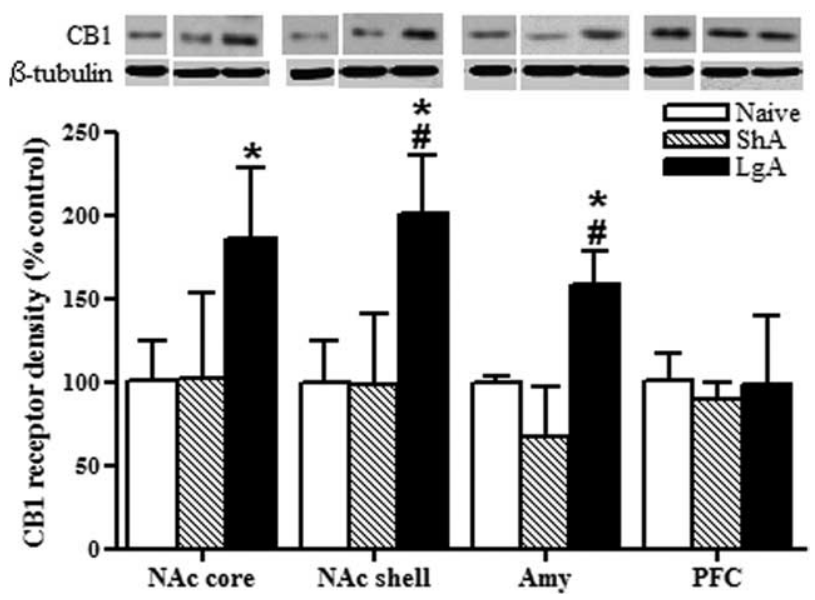

Figure 7. Upregulation of total $C B 1$ receptor density in NAc and Amy of $L g A$ rats. Quantification of total CB1 receptor density in the NAc core, NAc shell, Amy, and PFC of LgA (long access; filled bars), ShA (striped bars), and Naive (drug-naive; open bars) animals. Data in graphs are corrected for $\beta$-tubulin, expressed as percentage values of the drug-naive rats, and represented as mean $\pm \operatorname{SEM}(n=3-6)$. Animals were killed $24 \mathrm{~h}$ after the last cocaine session. Different from ShA animals, ${ }^{*} p<0.05$; different from ShA rats, ${ }^{\#} p<0.05$.

observed in ShA rats; (3) pCB1 and CB1 receptors are upregulated in the NAc and amygdala of LgA rats; (4) intra-NAc SR141716A infusions reduce cocaine breakpoints by LgA rats but not ShA rats.
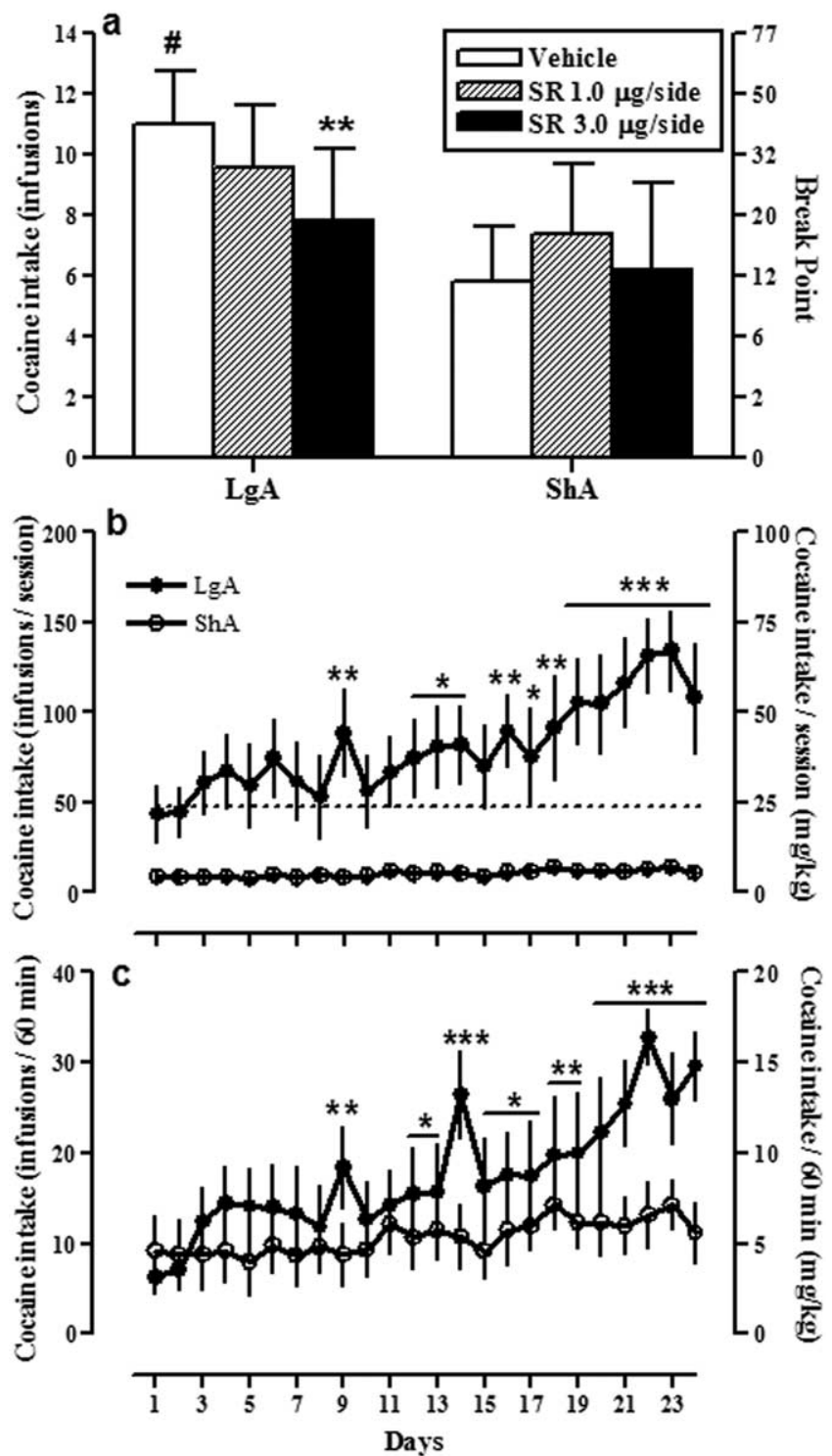

Figure 8. Intra-NAc infusions of SR141716A reduce cocaine breakpoints in LgA but not ShA rats. SR141716A (SR, Rimonabant) was infused locally into the NAc shell immediately before the test session $(\boldsymbol{a})$. Sessions under a PR schedule ended when rats did not achieve cocaine $(0.5$ $\mathrm{mg} / \mathrm{kg} /$ infusion) reinforcement within $1 \mathrm{~h}$. Data in $\boldsymbol{a}$ are expressed as the mean \pm SEM of the number of cocaine infusions per session on the left axis and the breakpoint (maximal ratio per infusion) on the right axis. Bars on the left side $(\boldsymbol{a})$ are data from cocaine extended-access ( $\operatorname{LgA})$ rats, and bars on the right side are data from limited-access (ShA) rats. Bilateral infusions of SR141716A ( $3.0 \mu \mathrm{g} / \mathrm{side})$ decreased the breakpoint for cocaine selectively in LgA rats compared with vehicle-injected animals. Different from vehicle-injected rats in the same access condition, ${ }^{* *} p<0.01$. Different from ShA vehicle-injected rats, ${ }^{\#} p<0.05$. Cocaine self-administration data (FR1) during the entire session ( $\boldsymbol{b}$ ) and the first hour of the session during the escalation period (c) are represented in the bottom graphs. Filled circles represent cocaine $(0.5 \mathrm{mg} / \mathrm{kg} /$ infusion) extended-access rats ( $6 \mathrm{~h}$ session, $\operatorname{Lg} \mathrm{A})$, and open circles correspond to cocainelimited-access rats ( $1 \mathrm{~h}$ session; ShA). Data are expressed as the mean $\pm \mathrm{SEM}$ of the number of cocaine infusions on the left axis and milligrams per kilograms on the right axis. ${ }^{*} p<0.05$, ${ }^{* *} p<0.01,{ }^{* * *} p<0.001$ compared with session one.

In agreement with previous reports, our LgA rats showed escalated cocaine intake and higher cocaine breakpoints versus the ShA rats, as an index of compulsivity and high motivation to seek cocaine associated with cocaine addiction (Koob, 2008; Wee et al., 2008). We observed enhanced sensitivity to CB1 receptor blockade in LgA rats, suggesting that $\mathrm{eCB}-\mathrm{CB} 1$ signaling is increased in extended-access animals. Furthermore, SR141716A 
suppressed responding comparably in LgA animals regardless of whether they were high or low responders for cocaine and reduced cocaine intake by LgA rats but not ShA rats that have similar amount of cocaine in the system during testing, which supports the finding that SR141716A was acting independently of response rate and amount of cocaine in the animals' system and was more potent in LgA rats.

Our present in vivo microdialysis study shows that accumbal AEA levels were decreased in ShA rats during cocaine selfadministration, whereas this effect was absent in LgA rats. We also did not observe cocaine-related changes in eCB levels after high doses of cocaine in previous studies (Caillé et al., 2007), where animals selfadministered cocaine during $90 \mathrm{~min}$ dialysis session at high doses $(\sim 15 \mathrm{mg} / \mathrm{kg})$ similar to LgA animals of this study $(\sim 20$ $\mathrm{mg} / \mathrm{kg}$ vs $\sim 5 \mathrm{mg} / \mathrm{kg}$ in ShA rats). Although the relative effect of the amount of cocaine intake on dialysate eCB levels requires further characterization, our present results highlight a potentially important difference in cocaine-induced alterations in NAc eCB levels between LgA and ShA animals. Although baseline AEA levels appear to be lower in the LgA group, the lack of cocaine-induced deficits in interstitial AEA levels in LgA rats suggests maintenance of eCB tone in these animals during cocaine intake that contrasts with a likely reduction in $\mathrm{CB} 1$ signaling during cocaine intake by ShA rats. Interestingly, resistance to cocaine-induced decreases in eCB levels apparently is insufficient to observe an effect of intra-NAc SR141716A, according to our previous studies (Caillé et al., 2007).

Clearly, some differences between our previous and present studies, such as session duration history and ratio schedules, likely contribute to the differential effects of SR141716A. Of equal or perhaps greater importance are the observations of upregulated pCB1 and CB1 receptor levels in the NAc of LgA rats. The combined observation of relatively greater accumbal AEA levels during cocaine self-administration with increased CB1 receptor protein in this region of $\mathrm{LgA}$ versus ShA rats is consistent with enhanced eCB signaling in LgA animals and the relatively greater sensitivity of these animals to $\mathrm{CB} 1$ antagonist-induced reductions in the motivational effects of cocaine.

The influence of $\mathrm{CB} 1$ receptor phosphorylation on eCB signaling is not well characterized. Recent evidence suggests that phosphorylation of the CB1 receptor distal carboxy terminus promotes internalization of agonist-activated full-length receptors (Daigle et al., 2008) similar to trafficking of delta opioid receptors (Whistler et al., 2001). Thus, it is conceivable that increased pCB1 reflects a compensatory response aimed at reducing CB1-mediated signaling as a consequence of a relative overactivation of the system (Garcia et al., 1998), although it is presently not possible to make strong conclusions in this regard. It is interesting, however, that others noted a correlation between increased CB1 receptor expression and increased pCB1 levels within distinct brain regions (Díaz-Asensio et al., 2008). Finally, demonstration that intra-NAc shell SR141716A infusions reduce cocaine breakpoints selectively in LgA rats supports the hypothesis that the NAc shell is a brain structure where eCB-CB1 signaling may participate in the compulsive and motivational aspects of cocaine addiction (Pontieri et al., 1995). However, we do not exclude an implication of the core subregion in this effect, since we found similar changes in $\mathrm{CB} 1$ and $\mathrm{pCB} 1$ proteins in both subregions. It is possible that several brain regions (i.e., shell, core, and/or amygdala) act together in the effect observed by SR141716A, since the systemic administration produced stronger reductions in cocaine breakpoints than the intra-NAc shell CB1 antagonist infusions.

CB1 receptors appear to play a role in the determination of the hedonic value and sensitivity to the rewarding properties of natural (Sanchís-Segura et al., 2004; Maccioni et al., 2008) and cocaine reinforcement (Deroche-Gamonet et al., 2001; Xi et al., 2008). Thus, it is possible that the increased motivation to obtain drug (as reflected by the increased effort under PR schedules) is particularly sensitive to SR141716A. This may explain why our LgA rats, which have enhanced motivation to seek cocaine hypothesized to be attributable to changes in hedonic set point (Ahmed et al., 2002), were much more sensitive to the effects of 
the CB1 antagonist. This hypothesis is consistent with previous reports, where CB1 antagonism was ineffective modulating limited-effort cocaine self-administration under FR schedules (Fattore et al., 1999; Tanda et al., 2000; De Vries et al., 2001; Lesscher et al., 2005; Soria et al., 2005; Caillé and Parsons, 2006; Caillé et al., 2007; Xi et al., 2008) but effective under PR schedules (Soria et al., 2005; Xi et al., 2008). Recently, Xi et al. (2008) showed that high doses of systemic SR141716A were ineffective modulating PR cocaine self-administration in limited-access rats, but $3.0 \mathrm{mg} / \mathrm{kg}$ of the potent $\mathrm{CB} 1$ antagonist AM 251 reduced cocaine responding. We found that SR141716A clearly reduces cocaine breakpoints in LgA rats, even at low doses such as 0.3 $\mathrm{mg} / \mathrm{kg}$, which make SR effects more selective for cocaine extended-access rats. However, we also observed a decrease in PR responding in the ShA group with the highest dose of SR, in contrast to Xi et al. (2008). The reasons for the discrepancy between studies are not clear. The fact that intra-accumbal injections of SR141716A in the present study decreased cocaine breakpoints only in $\operatorname{LgA}$ rats and not in ShA rats at the doses tested strengthens the conclusion that SR141716A acts selectively for cocaine extended-access animals. However, one cannot exclude the possibility that relatively high doses of SR141716A (this study) or high selective CB1-antagonist (Xi et al., 2008) may also decrease cocaine-maintained behavior by ShA rats.

The neuropharmacological mechanism by which CB1 receptors could modulate motivational aspects of increased cocaine intake is unknown. Studies suggest potential interactions of CB1 receptor activation with the dopamine and/or glutamate systems. Cocaine addiction is associated with decreases in NAc basal dopamine levels (Weiss et al., 1992) and striatal $\mathrm{D}_{2}$ receptors (Volkow et al., 1999; Nader et al., 2006; Dalley et al., 2007). A compromised postsynaptic $\mathrm{D}_{2}$-like receptor function in LgA animals may contribute to an upregulated cAMP-PKA signaling in the NAc, which is known to underlie tolerance to cocaine reinforcement (Self et al., 1998; but see Lynch and Taylor, 2005) and is also a requirement for AEA formation in neurons (Cadas et al., 1996). This hypothesis may explain why the LgA rats, which have compromised $D_{1} / D_{2}$ function (Ahmed and Koob, 2004), also present a maintained AEA tone compared with ShA animals (this study). Nevertheless, other reports indicate that, behaviorally, cocaine addiction increased $\mathrm{D}_{2}$ receptor function or sensitization (De Vries et al., 2002; Edwards et al., 2007), and, interestingly, striatal $\mathrm{D}_{2}$ activation may be also responsible for AEA release (Giuffrida et al., 1999; Beltramo et al., 2000; Centonze et al., 2004). Alternatively, a maintained AEA tone in LgA rats could be explained by an alteration in the mechanisms of eCB degradation and not in the biosynthesis, as reported for ethanol preference (Hansson et al., 2007).

The CB1 signaling upregulation proposed in this study and the reduced glutamatergic activity observed in escalated animals (Allen et al., 2007) suggest that a retrograde eCB signaling in LgA animals may inhibit glutamate transmission via activation of presynaptic CB1 receptors located in NAc glutamate terminals (Gerdeman et al., 2002; Robbe et al., 2002). Thus, CB1 antagonists could neutralize a CB1-mediated inhibition of glutamate input (Xi et al., 2006) onto AMPA receptors in medium spiny neurons, normalizing the cocaine-evoked NAc synaptic plasticity that underlies the addictive behavior (Bachtell et al., 2008; Conrad et al., 2008). Alternatively, since dopaminergic and eCB systems exert mutual control on each other (van der Stelt and Di Marzo, 2003), it is also conceivable that the dopamine function impairment in LgA rats (Ahmed and Koob, 2004) may be the result of enhanced chronic CB1 neurotransmission, because of an eCB inhibitory feedback mechanism countering dopamine function (Giuffrida et al., 1999; Beltramo et al., 2000).

Together, our results suggest that eCB system neuroplasticity in the NAc may contribute to the motivational drive for cocaine associated with uncontrolled psychostimulant use and, therefore, may be a target for cocaine addiction pharmacotherapies.

\section{References}

Ahmed SH, Koob GF (1998) Transition from moderate to excessive drug intake: change in hedonic set point. Science 282:298-300.

Ahmed SH, Koob GF (1999) Long-lasting increase in the set point for cocaine self-administration after escalation in rats. Psychopharmacology (Berl) 146:303-312.

Ahmed SH, Koob GF (2004) Changes in response to a dopamine receptor antagonist in rats with escalating cocaine intake. Psychopharmacology (Berl) 172:450-454.

Ahmed SH, Koob GF (2005) Transition to drug addiction: a negative reinforcement model based on an allostatic decrease in reward function. Psychopharmacology (Berl) 180:473-490.

Ahmed SH, Kenny PJ, Koob GF, Markou A (2002) Neurobiological evidence for hedonic allostasis associated with escalating cocaine use. Nat Neurosci 5:625-626.

Allen RM, Dykstra LA, Carelli RM (2007) Continuous exposure to the competitive N-methyl-D: -aspartate receptor antagonist, LY235959, facilitates escalation of cocaine consumption in Sprague-Dawley rats. Psychopharmacology (Berl) 191:341-351.

American Psychiatric Association (2000) Diagnostic and statistical manual of mental disorders, IV-TR edition. Washington, DC: American Psychiatric.

Bachtell RK, Choi KH, Simmons DL, Falcon E, Monteggia LM, Neve RL, Self DW (2008) Role of GluR1 expression in nucleus accumbens neurons in cocaine sensitization and cocaine-seeking behavior. Eur J Neurosci $27: 2229-2240$

Basavarajappa BS, Cooper TB, Hungund BL (1998) Chronic ethanol administration down-regulates cannabinoid receptors in mouse brain synaptic plasma membrane. Brain Res 793:212-218.

Beltramo M, de Fonseca FR, Navarro M, Calignano A, Gorriti MA, Grammatikopoulos G, Sadile AG, Giuffrida A, Piomelli D (2000) Reversal of dopamine $\mathrm{D}_{2}$ receptor responses by an anandamide transport inhibitor. J Neurosci 20:3401-3407.

Cadas H, Gaillet S, Beltramo M, Venance L, Piomelli D (1996) Biosynthesis of an endogenous cannabinoid precursor in neurons and its control by calcium and cAMP. J Neurosci 16:3934-3942.

Caillé S, Parsons LH (2006) Cannabinoid modulation of opiate reinforcement through the ventral striatopallidal pathway. Neuropsychopharmacology 31:804-813.

Caillé S, Alvarez-Jaimes L, Polis I, Stouffer DG, Parsons LH (2007) Specific alterations of extracellular endocannabinoid levels in the nucleus accumbens by ethanol, heroin, and cocaine self-administration. J Neurosci 27:3695-3702.

Centonze D, Battista N, Rossi S, Mercuri NB, Finazzi-Agrò A, Bernardi G, Calabresi P, Maccarrone M (2004) A critical interaction between dopamine D2 receptors and endocannabinoids mediates the effects of cocaine on striatal gabaergic transmission. Neuropsychopharmacology 29:1488-1497.

Cohen C, Kodas E, Griebel G (2005) CB1 receptor antagonists for the treatment of nicotine addiction. Pharmacol Biochem Behav 81:387-395.

Conrad KL, Tseng KY, Uejima JL, Reimers JM, Heng LJ, Shaham Y, Marinelli M, Wolf ME (2008) Formation of accumbens GluR2-lacking AMPA receptors mediates incubation of cocaine craving. Nature 454:118-121.

Cossu G, Ledent C, Fattore L, Imperato A, Böhme GA, Parmentier M, Fratta W (2001) Cannabinoid CB1 receptor knockout mice fail to selfadminister morphine but not other drugs of abuse. Behav Brain Res 118:61-65.

Daigle TL, Kwok ML, Mackie K (2008) Regulation of CB1 cannabinoid receptor internalization by a promiscuous phosphorylation-dependent mechanism. J Neurochem 106:70-82.

Dalley JW, Fryer TD, Brichard L, Robinson ES, Theobald DE, Lääne K, Peña Y, Murphy ER, Shah Y, Probst K, Abakumova I, Aigbirhio FI, Richards HK, Hong Y, Baron JC, Everitt BJ, Robbins TW (2007) Nucleus accumbens D2/3 receptors predict trait impulsivity and cocaine reinforcement. Science 315:1267-1270. 
Deroche V, Le Moal M, Piazza PV (1999) Cocaine self-administration increases the incentive motivational properties of the drug in rats. Eur J Neurosci 11:2731-2736.

Deroche-Gamonet V, Le MM, Piazza PV, Soubrie P (2001) SR141716, a CB1 receptor antagonist, decreases the sensitivity to the reinforcing effects of electrical brain stimulation in rats. Psychopharmacology (Berl) 157:254-259.

De Vries TJ, Shaham Y, Homberg JR, Crombag H, Schuurman K, Dieben J, Vanderschuren LJ, Schoffelmeer AN (2001) A cannabinoid mechanism in relapse to cocaine seeking. Nat Med 7:1151-1154.

De Vries TJ, Schoffelmeer AN, Binnekade R, Raasø H, Vanderschuren LJ (2002) Relapse to cocaine- and heroin-seeking behavior mediated by dopamine $\mathrm{D} 2$ receptors is time-dependent and associated with behavioral sensitization. Neuropsychopharmacology 26:18-26.

Díaz-Asensio C, Setién R, Echevarría E, Casis L, Casis E, Garrido A, Casis O (2008) Type 1 diabetes alters brain cannabinoid receptor expression and phosphorylation status in rats. Horm Metab Res 40:454-458.

Edwards S, Whisler KN, Fuller DC, Orsulak PJ, Self DW (2007) Addictionrelated alterations in D1 and D2 dopamine receptor behavioral responses following chronic cocaine self-administration. Neuropsychopharmacology 32:354-366.

Fattore L, Martellotta MC, Cossu G, Mascia MS, Fratta W (1999) CB1 cannabinoid receptor agonist WIN 55,212-2 decreases intravenous cocaine self-administration in rats. Behav Brain Res 104:141-146.

Filip M, Gołda A, Zaniewska M, McCreary AC, Nowak E, Kolasiewicz W, Przegaliński E (2006) Involvement of cannabinoid CB1 receptors in drug addiction: effects of rimonabant on behavioral responses induced by cocaine. Pharmacol Rep 58:806-819.

Fusco FR, Martorana A, Giampà C, De March Z, Farini D, D’Angelo V, Sancesario G, Bernardi G (2004) Immunolocalization of CB1 receptor in rat striatal neurons: a confocal microscopy study. Synapse 53:159-167.

Garcia DE, Brown S, Hille B, Mackie K (1998) Protein kinase C disrupts cannabinoid actions by phosphorylation of the CB1 cannabinoid receptor. J Neurosci 18:2834-2841.

Gardner EL (2005) Endocannabinoid signaling system and brain reward: emphasis on dopamine. Pharmacol Biochem Behav 81:263-284.

Gérard CM, Mollereau C, Vassart G, Parmentier M (1991) Molecular cloning of a human cannabinoid receptor which is also expressed in testis. Biochem J 279:129-134.

Gerdeman GL, Ronesi J, Lovinger DM (2002) Postsynaptic endocannabinoid release is critical to long-term depression in the striatum. Nat Neurosci 5:446-451.

Giuffrida A, Parsons LH, Kerr TM, Rodríguez de Fonseca F, Navarro M, Piomelli D (1999) Dopamine activation of endogenous cannabinoid signaling in dorsal striatum. Nat Neurosci 2:358-363.

Gonzalez S, Fernandez-Ruiz J, Sparpaglione V, Parolaro D, Ramos JA (2002) Chronic exposure to morphine, cocaine or ethanol in rats produced different effects in brain cannabinoid $\mathrm{CB}(1)$ receptor binding and mRNA levels. Drug Alcohol Depend 66:77-84.

Hansson AC, Bermúdez-Silva FJ, Malinen H, Hyytiä P, Sanchez-Vera I, Rimondini R, Rodriguez de Fonseca F, Kunos G, Sommer WH, Heilig M (2007) Genetic impairment of frontocortical endocannabinoid degradation and high alcohol preference. Neuropsychopharmacology 32:117-126.

Herkenham M, Lynn AB, Little MD, Johnson MR, Melvin LS, de Costa BR, Rice KC (1990) Cannabinoid receptor localization in brain. Proc Natl Acad Sci U S A 87:1932-1936.

Herkenham M, Lynn AB, Johnson MR, Melvin LS, de Costa BR, Rice KC (1991) Characterization and localization of cannabinoid receptors in rat brain: a quantitative in vitro autoradiographic study. J Neurosci 11:563-583.

Hermann H, Lutz B (2005) Coexpression of the cannabinoid receptor type 1 with the corticotropin-releasing hormone receptor type 1 in distinct regions of the adult mouse forebrain. Neurosci Lett 375:13-18.

Howlett AC, Song C, Berglund BA, Wilken GH, Pigg JJ (1998) Characterization of $\mathrm{CB} 1$ cannabinoid receptors using receptor peptide fragments and site-directed antibodies. Mol Pharmacol 53:504-510.

Kitamura O, Wee S, Specio SE, Koob GF, Pulvirenti L (2006) Escalation of methamphetamine self-administration in rats: a dose-effect function. Psychopharmacology (Berl) 186:48-53.

Koob GF (2008) A role for brain stress systems in addiction. Neuron 59:11-34.
Lesscher HM, Hoogveld E, Burbach JP, van Ree JM, Gerrits MA (2005) Endogenous cannabinoids are not involved in cocaine reinforcement and development of cocaine-induced behavioural sensitization. Eur Neuropsychopharmacol 15:31-37.

Lupica CR, Riegel AC, Hoffman AF (2004) Marijuana and cannabinoid regulation of brain reward circuits. Br J Pharmacol 143:227-234.

Lynch WJ, Taylor JR (2005) Persistent changes in motivation to selfadminister cocaine following modulation of cyclic AMP-dependent protein kinase A (PKA) activity in the nucleus accumbens. Eur J Neurosci 22:1214-1220.

Maccioni P, Pes D, Carai MA, Gessa GL, Colombo G (2008) Suppression by the cannabinoid CB1 receptor antagonist, rimonabant, of the reinforcing and motivational properties of a chocolate-flavoured beverage in rats. Behav Pharmacol 19:197-209.

Mailleux P, Vanderhaeghen JJ (1992) Distribution of neuronal cannabinoid receptor in the adult rat brain: a comparative receptor binding radioautography and in situ hybridization histochemistry. Neuroscience 48:655-668.

Martin M, Ledent C, Parmentier M, Maldonado R, Valverde O (2000) Cocaine, but not morphine, induces conditioned place preference and sensitization to locomotor responses in CB1 knockout mice. Eur J Neurosci 12:4038-4046.

Matsuda LA, Lolait SJ, Brownstein MJ, Young AC, Bonner TI (1990) Structure of a cannabinoid receptor and functional expression of the cloned cDNA. Nature 346:561-564.

Nader MA, Morgan D, Gage HD, Nader SH, Calhoun TL, Buchheimer N, Ehrenkaufer R, Mach RH (2006) PET imaging of dopamine D2 receptors during chronic cocaine self-administration in monkeys. Nat Neurosci 9:1050-1056.

National Surveys on Drug Use and Health (2006) Survey: 2006 NSDHU: national findings. Office of Applied Studies. Substance Abuse and Mental Health Services Administration (SAMHSA), Rockville, MD.

Navarro M, Carrera MR, Fratta W, Valverde O, Cossu G, Fattore L, Chowen JA, Gomez R, del Arco I, Villanua MA, Maldonado R, Koob GF, Rodriguez de Fonseca $F$ (2001) Functional interaction between opioid and cannabinoid receptors in drug self-administration. J Neurosci 21:5344-5350.

Navarro M, Carrera MR, Del Arco I, Trigo JM, Koob GF, Rodríguez de Fonseca F (2004) Cannabinoid receptor antagonist reduces heroin selfadministration only in dependent rats. Eur J Pharmacol 501:235-237.

Paterson NE, Markou A (2003) Increased motivation for self-administered cocaine after escalated cocaine intake. Neuroreport 14:2229-2232.

Paxinos G, Watson C (1998) The rat brain in stereotaxic coordinates. New York: Academic.

Pontieri FE, Tanda G, Di Chiara G (1995) Intravenous cocaine, morphine, and amphetamine preferentially increase extracellular dopamine in the "shell" as compared with the "core" of the rat nucleus accumbens. Proc Natl Acad Sci U S A 92:12304-12308.

Porcella A, Maxia C, Gessa GL, Pani L (2000) The human eye expresses high levels of CB1 cannabinoid receptor mRNA and protein. Eur J Neurosci 12:1123-1127.

Richardson NR, Roberts DC (1996) Progressive ratio schedules in drug selfadministration studies in rats: a method to evaluate reinforcing efficacy. J Neurosci Methods 66:1-11.

Rimondini R, Arlinde C, Sommer W, Heilig M (2002) Long-lasting increase in voluntary ethanol consumption and transcriptional regulation in the rat brain after intermittent exposure to alcohol. FASEB J 16:27-35.

Robbe D, Kopf M, Remaury A, Bockaert J, Manzoni OJ (2002) Endogenous cannabinoids mediate long-term synaptic depression in the nucleus accumbens. Proc Natl Acad Sci U S A 99:8384-8388.

Rodríguez de Fonseca F, Roberts AJ, Bilbao A, Koob GF, Navarro M (1999) Cannabinoid receptor antagonist SR141716A decreases operant ethanol self administration in rats exposed to ethanol-vapor chambers. Zhongguo Yao Li Xue Bao 20:1109-1114.

Sanchís-Segura C, Cline BH, Marsicano G, Lutz B, Spanagel R (2004) Reduced sensitivity to reward in CB1 knockout mice. Psychopharmacology (Berl) 176:223-232.

Self DW, Genova LM, Hope BT, Barnhart WJ, Spencer JJ, Nestler EJ (1998) Involvement of cAMP-dependent protein kinase in the nucleus accumbens in cocaine self-administration and relapse of cocaine-seeking behavior. J Neurosci 18:1848-1859.

Soria G, Mendizábal V, Touriño C, Robledo P, Ledent C, Parmentier M, 
Maldonado R, Valverde O (2005) Lack of CB1 cannabinoid receptor impairs cocaine self-administration. Neuropsychopharmacology 30:1670-1680.

Specio SE, Wee S, O’Dell LE, Boutrel B, Zorrilla EP, Koob GF (2008) CRF(1) receptor antagonists attenuate escalated cocaine self-administration in rats. Psychopharmacology (Berl) 196:473-482.

Tanda G, Goldberg SR (2003) Cannabinoids: reward, dependence, and underlying neurochemical mechanisms-a review of recent preclinical data. Psychopharmacology (Berl) 169:115-134.

Tanda G, Munzar P, Goldberg SR (2000) Self-administration behavior is maintained by the psychoactive ingredient of marijuana in squirrel monkeys. Nat Neurosci 3:1073-1074.

Tsou K, Brown S, Sañudo-Peña MC, Mackie K, Walker JM (1998) Immunohistochemical distribution of cannabinoid $\mathrm{CB} 1$ receptors in the rat central nervous system. Neuroscience 83:393-411.

van der Stelt M, Di Marzo V (2003) The endocannabinoid system in the basal ganglia and in the mesolimbic reward system: implications for neurological and psychiatric disorders. Eur J Pharmacol 480:133-150.

Volkow ND, Fowler JS, Wang GJ (1999) Imaging studies on the role of dopamine in cocaine reinforcement and addiction in humans. J Psychopharmacol 13:337-345.

Wee S, Specio SE, Koob GF (2007) Effects of dose and session duration on cocaine self-administration in rats. J Pharmacol Exp Ther 320:1134-1143.

Wee S, Mandyam CD, Lekic DM, Koob GF (2008) Alpha 1-noradrenergic system role in increased motivation for cocaine intake in rats with prolonged access. Eur Neuropsychopharmacol 18:303-311.

Weiss F, Markou A, Lorang MT, Koob GF (1992) Basal extracellular dopamine levels in the nucleus accumbens are decreased during cocaine withdrawal after unlimited-access self-administration. Brain Res 593:314-318.

Whistler JL, Tsao P, von Zastrow M (2001) A phosphorylation-regulated brake mechanism controls the initial endocytosis of opioid receptors but is not required for post-endocytic sorting to lysosomes. J Biol Chem 276:34331-34338.

Wiskerke J, Pattij T, Schoffelmeer AN, De Vries TJ (2008) The role of CB1 receptors in psychostimulant addiction. Addict Biol 13:225-238.

Xi ZX, Gilbert JG, Pak AC, Ashby CR Jr, Heidbreder CA, Gardner EL (2005) Selective dopamine D3 receptor antagonism by SB-277011A attenuates cocaine reinforcement as assessed by progressive-ratio and variable-costvariable-payoff fixed-ratio cocaine self-administration in rats. Eur J Neurosci 21:3427-3438.

Xi ZX, Gilbert JG, Peng XQ, Pak AC, Li X, Gardner EL (2006) Cannabinoid CB1 receptor antagonist AM251 inhibits cocaine-primed relapse in rats: role of glutamate in the nucleus accumbens. J Neurosci 26:8531-8536.

Xi ZX, Spiller K, Pak AC, Gilbert J, Dillon C, Li X, Peng XQ, Gardner EL (2008) Cannabinoid CB1 receptor antagonists attenuate cocaine's rewarding effects: experiments with self-administration and brainstimulation reward in rats. Neuropsychopharmacology 33:1735-1745. 